Section Editor Mitchell S.V. Elkind, MD, MS

\title{
Teaching Video NeuroImages:
} Hand tremor, tongue and perioral fasciculation in a patient with Kennedy disease 自

Mohammad Rohani, MD Shahnaz Miri, MD

Correspondence to Dr. Rohani:

mohammadroohani@gmail.com
A 54-year-old man presented with a 10-year history of progressive gait difficulty, muscle weakness, and fatigue. Clinical examinations revealed mild nasal speech; postural hand tremor; absence of deep tendon reflexes; atrophy and fasciculation in tongue, facial (perioral), and limb muscles; and gynecomastia (video on the Neurology ${ }^{\circledR}$ Web site at Neurology.org). Nerve conduction studies had normal results; however, needle EMG demonstrated a neurogenic pattern with spontaneous activity (fibrillation, positive sharp wave, and fasciculation) in cranial and limb muscles. Genetic testing confirmed (CAG expansion of the androgen receptor gene on $\mathrm{X}$ chromosome) the diagnosis of spinobulbar muscular atrophy or Kennedy disease, an X-linked adult-onset degenerative disorder of motor neurons. ${ }^{1,2}$

\section{AUTHOR CONTRIBUTIONS}

Dr. Mohammad Rohani: acquisition of data, drafting and revising the manuscript. Dr. Shahnaz Miri: drafting and revising the manuscript.

\section{STUDY FUNDING}

No targeted funding reported.

\section{DISCLOSURE}

The authors report no disclosures relevant to the manuscript. Go to Neurology.org for full disclosures.

\section{REFERENCES}

1. Finsterer J. Bulbar and spinal muscular atrophy (Kennedy's disease): a review. Eur J Neurol 2009;16:556-561.

2. Harding AE, Thomas PK, Baraitser M, Bradbury PG, Morgan-Hughes JA, Ponsford JR. X-linked recessive bulbospinal neuronopathy: a report of ten cases. J Neurol Neurosurg Psychiatry 1982;45:1012-1019.
Download teaching slides: Neurology.org

Supplemental data at Neurology.org
From the Department of Neurology (M.R.), Iran University of Medical Sciences, Tehran, Iran; and the Department of Neurology (S.M.), SUNY Downstate Medical Center, Brooklyn, NY. 


\section{Neurology}

\section{Teaching Video NeuroImages: Hand tremor, tongue and perioral fasciculation in a patient with Kennedy disease}

Mohammad Rohani and Shahnaz Miri

Neurology 2015;84;e76

DOI 10.1212/WNL.0000000000001340

\section{This information is current as of March 9, 2015}

\section{Updated Information \&} Services

\section{Supplementary Material}

\section{References}

Subspecialty Collections

Permissions \& Licensing

Reprints including high resolution figures, can be found at: http://n.neurology.org/content/84/10/e76.full

Supplementary material can be found at: http://n.neurology.org/content/suppl/2015/03/07/WNL.0000000000001 340.DC1

http://n.neurology.org/content/suppl/2015/03/07/WNL.0000000000001 340.DC2

This article cites 2 articles, 1 of which you can access for free at: http://n.neurology.org/content/84/10/e76.full\#ref-list-1

This article, along with others on similar topics, appears in the following collection(s):

\section{Anterior nerve cell disease}

http://n.neurology.org/cgi/collection/anterior_nerve_cell_disease Other Education

http://n.neurology.org/cgi/collection/other_education

Tremor

http://n.neurology.org/cgi/collection/tremor

Trinucleotide repeat diseases

http://n.neurology.org/cgi/collection/trinucleotide_repeat_diseases

Information about reproducing this article in parts (figures,tables) or in its entirety can be found online at:

http://www.neurology.org/about/about_the_journal\#permissions

Information about ordering reprints can be found online:

http://n.neurology.org/subscribers/advertise

Neurology ${ }^{\circledR}$ is the official journal of the American Academy of Neurology. Published continuously since 1951, it is now a weekly with 48 issues per year. Copyright @ 2015 American Academy of Neurology. All rights reserved. Print ISSN: 0028-3878. Online ISSN: 1526-632X.

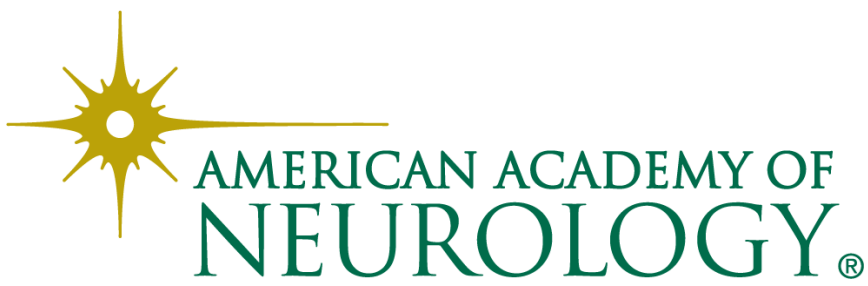

